\title{
The Expression of P-Selectin and GP53 is Dependent on Stent Length: A Flow Cytometric Evaluation of Stainless Steel Stent-Induced Platelet Activation in an In-Vitro Model
}

\author{
Die Expression von P-Selektin und GP53 ist abhängig von der Stentlänge. \\ Eine durchflußzytometrische Analyse einer durch Edelstahlstents induzierten \\ Plättchenaktivierung in einem in-vitro-Modell
}

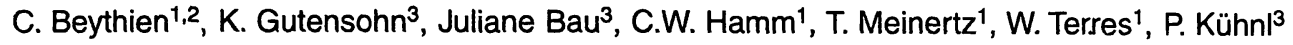

\begin{abstract}
Summary: Activated platelets are involved in the process of acute and subacute thrombotic occlusion and restenosis after placement of stents in coronary arteries. In an in vitro model of stent thrombosis we investigated the influence of stent length on the expression of platelet glycoproteins by flow cytometry, and on the time until thrombotic occlusion of stents. Stainless steel stents (each $n=7$ ) were placed in parallel silicon tubes with circulating citrated platelet rich plasma (PRP). After recalcification, aliquots of PRP were taken every two minutes. Monoclonal antibodies against CD41a (GP IIb-IIIa), CD42b (GP Ib-V-IX), CD62p (P-selectin) and CD63 (GP 53) were used for flow cytometric analysis. Within $2 \mathrm{~min}$ after start of circulation, mean channel fluorescence intensity of CD62p and CD63 increased in the tubing system with the stents, and over 10 min platelet activation notably increased. Significant differences could be detected between $9 \mathrm{~mm}$ and $18 \mathrm{~mm}$ stents $(p<0.005)$. CD41a and $C D 42 b$ did not show significant changes. Time until stent thrombosis was also dependent on stent length: $18 \mathrm{~mm}$ stents thrombosed earlier than $9 \mathrm{~mm}$ stents $(p<0.01)$.
\end{abstract}

Keywords: Stents/adverse effects; Thrombosis; Platelet Activation; Glycoproteins; Flow Cytometry.

Zusammenfassung: Aktivierte Blutplättchen sind an akuten und subakuten thrombotischen Verschlüssen sowie an Restenosen von Stents in Koronarien beteiligt. In einem in vitro Thrombosemodell untersuchten

\footnotetext{
1 Abteilung fûr Kardiologie. Universitäts-Krankenhaus Eppendorf, Hamburg

${ }^{2}$ Author for correspondence: Dr. Christian Beythien, UniversitätsKrankenhaus Eppendorf, Medizinische Klinik. Abteilung für Kardiologie, Martinistraße 52, D-20246 Hamburg, Germany. Fax: +49-40-4717-4938; E-Mail: beythien@uke.uni-hamburg.de

3 Abteilung for Transfusionsmedizin und Transplantationsimmunologie. Universitäts-Krankenhaus Eppendorf, Hamburg Received: February 18, 1998
}

wir mittels der Durchflußzytometrie die Expression von Plättchenglykoproteinen und die Zeit bis zur Stentthrombose. Edelstahlstents (jeweils $n=7$ ) wurden in parallele Silikonschläuche mit zirkulierendem plättchen-reichen Zitratplasma (PRP) implantiert. Nach der Rekalzifizierung wurden alle zwei Minuten PRP-Proben entnommen. Zur durchflußzytometrischen Untersuchung wurden die monoklonalen Antikörper gegen CD41a (GP Ilb-IIIa), CD42b (GP lb-V-IX), CD62p (PSelectin) und CD63 (GP 53) verwendet. Zwei Minuten nach Start der Zirkulation nahm die „Mean Channel Fluorescence Intensity" von CD62p und CD63 in den Schlauchsystemen mit den Stents zu und stieg über zehn Minuten deutlich an. Zwischen $9 \mathrm{~mm}$ und $18 \mathrm{~mm}$ langen Stents konnten dabei signifikante Unterschiede nachgewiesen werden $(p<0,005)$. Bei CD41a und $\mathrm{CD} 42 \mathrm{~b}$ zeigten sich keine signifikanten Unterschiede. Die Zeit bis zur Stentthrombose war ebenfalls von der Stentlänge abhängig; $18 \mathrm{~mm}$ Stents thrombosierten früher als $9 \mathrm{~mm}$ Stents $(p<0,01)$.

Schlüsselwörter: Stents/Unerwünschte Wirkungen; Thrombose; Plättchenaktivierung; Glykoproteine; Durchflußzytometrie.

\footnotetext{
The implantation of stents is meanwhile a well approved method to treat acute or threatening occlusion and restenosis after percutaneous balloon angioplasty of coronary arteries (PTCA) [1-3]. However, this technique is limited by the risk of intra-stent thrombotic occlusion [4-6]. Activated platelets are involved in this pathophysiological process [7-9]. The foreign surface, mechanical alteration or flow disturbances in stents may cause activation of platelets. To further evaluate the impact of stents on platelets ive investigated different stent lengths by determining the expression of glycoproteins on platelets by flow cytometry. In addition, to study the influence on coagulation, the time until thrombotic occlusion of stents was measured.
} 
Figure 1 CD62P (P-selectin) and CD63 (glycoprotein 53) "Mean channel fluorescence intensity" at the initiation of circulation and after $10 \mathrm{~min}$.

Stent length 9 vs $18 \mathrm{~mm}$ after $10 \mathrm{~min}$ $p<0.005$

Stent length $9 \mathrm{~mm}$ vs control after 10 $\min p<0.01$

Stent length $18 \mathrm{~mm}$ vs control after 10 $\min p<0.0005$

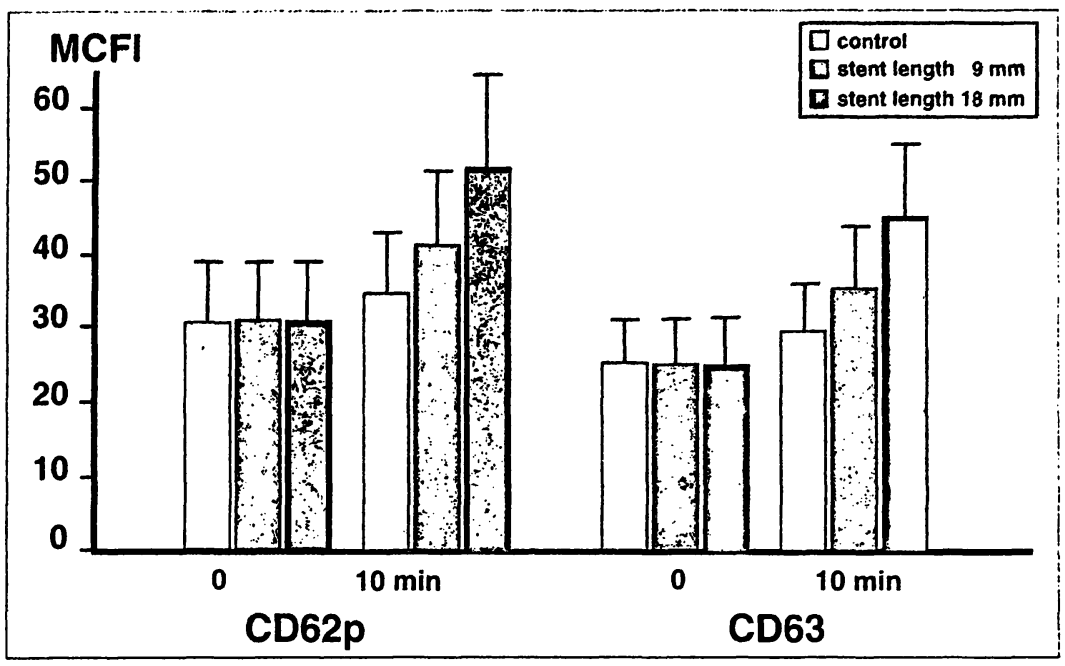

\section{Methods}

A previously described in vitro model was used $[7,8]$ to study changes of platelet antigens induced by stainless steel coronary stents (each $n=7$ ). In each test, three parallel systems were used, two with different stent lengths ( 9 and $18 \mathrm{~mm}$ ), and one tubing without stents (control).

At 2, 4, 6,.8 and $10 \mathrm{~min}$, aliquots of platelet rich plasma were taken via a three-way tag. $100 \mu l$ of PRP were removed with a pipette and immediately transferred into polystyrene tubes containing a stabilization solution with glyoxal 40\% (Merck, Darmstadt, FRG), paraformaldehyde $10 \%$ (Serva, Heidelberg, FRG) and phosphate buffer $0.15 \mathrm{~mol} / \mathrm{l}$ (Merck). After incubation for $10 \mathrm{~min}$, the samples were diluted 1:10 with phosphate buffer containing $0.2 \% \mathrm{w} / \mathrm{v}$ of glycine (Serva) and then stored at $4^{\circ} \mathrm{C}[10]$. Each sample was labeled with monoclonal antibodies for $30 \mathrm{~min}$ at room temperature in the dark. Subsequently, samples were washed once with PBS, resuspended in $1000 \mu \mathrm{l}$ PBS and stored for flow cytometric analysis.

For flow cytometric analysis monoclonal antibodies CD41a (GP Ilb-IIIa), CD42b (GP lb-V-IX), CD62p (Pselectin) and CD63 (GP 53) were used in direct assays. Antibodies were directly conjugated with fluoresceinisothiocyanate (FITC) or phycoerythrin (PE). IgG was used as isotype control (all monoclonal antibodies from Beckman-Coulter, Fullerton, USA.

Flow cytometric analysis was performed on a FACScan cytometer (Becton Dickinson, Mountain View, USA). In a log forward angle light scatter (FSC) and $\log 90^{\circ}$ side scatter (SSC) the appropriate threshold was set to exclude debris and electronic noise.

Non standard abbreviations: $C D$, cluster designation; FITC, fluorescein isothiocyanate; FSC, forward scatter; GP, glycoprotein; $P E$, phycoerythrin; PRP, platelet-rich plasma; PTCA, percutaneous, transluminal coronary angioplasty; SSC, side scatter.
Platelets were primary distinguished on the basis of their FSC/SSC profile. In each sample 50,000 events were analyzed. Results were expressed as mean channel fluorescence intensity (MCFI). Antibody positive cells were defined as cells with a fluorescence higher than the isotype control.

\section{Results}

After recalcification and start of circulation, expression of activation dependent antigens CD62p and CD63 increased within $2 \mathrm{~min}$ in the tubings with stents. Over 10 min platelet activation increased. CD62p or CD63 positive peaks showed an increasing right shift on the histogram $\mathrm{x}$-axis, demonstrating progressive cell activation.

Fluorescence intensity of CD41a and CD42b did not show significant changes in all systems applied.

Longer stents led to significantly more platelet activation than shorter stents; $9 \mathrm{~mm}$ vs. $18 \mathrm{~mm}, \mathrm{p}<0.005$. After 10 min mean channel fluorescence intensity for CD62p was $41.6 \pm 9.7$ and $52.1 \pm 11.5$, and for CD63 $35.7 \pm 7.8$ and $44.9 \pm 9.9$ respectively. Control tubings without stents showed significantly less activation. After 10 min mean channel fluorescence intensity was $34.2 \pm 8.3$ for CD62p and $29.6 \pm 6.6$ for CD63; control versus $9 \mathrm{~mm}$ stents $\mathrm{p}<0.01$, versus $18 \mathrm{~mm}$ stents $\mathrm{p}<0.001$ (Fig .1). Antigens CD41a and CD42b did not show significant changes. Time until stent thrombosis was also dependent on stent length. Eighteen mm stent thrombosed earlier than $9 \mathrm{~mm}$ stents; $13.5 \pm 4.2$ vs $16.9 \pm 3.7 \mathrm{~min}(\mathrm{p}<0.01$, Figure 2$)$.

\section{Discussion}

Coronary stents appear to be a promising approach in the therapy of restenosis and acute closure after PTCA 


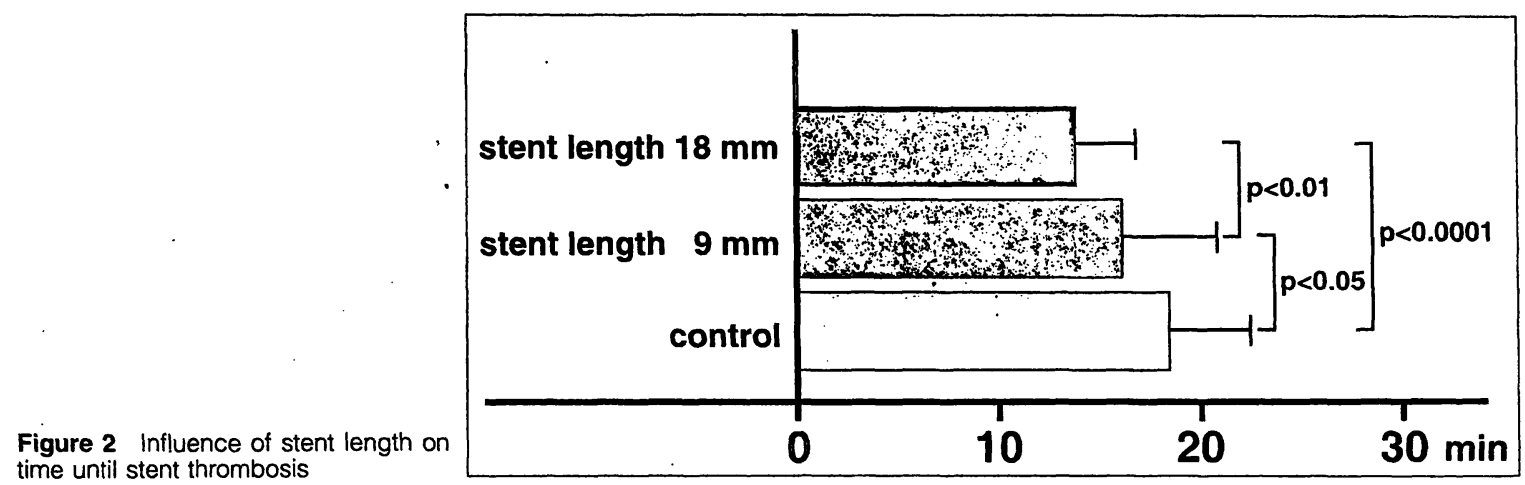

[1]. Unfortunately, stents are thrombogenic and the application of this device is restricted by acute and subacute thrombotic closure [2-4]. Since activated platelets are basically involved in this process [5-7], we investigated the expression of platelet antigens and assessed the time until thrombotic stent occlusion in an in vitro model of stent thrombosis.

With the development of monoclonal antibodies against platelet membrane glycoproteins, investigations of cell surface antigens have been facilitated. For their detection the technique of flow cytometry can be used [11]. This method allows the examination of large numbers of single cells as well as the detection and quantification of changes in surface antigen expression in activated subpopulations.

During activation, P-selectin is cleared from internal $\alpha$-granules that fuse with the plasma membrane. This neoantigen was first described by McEver et al. [12] and is only expressed on the surface of activated platelets. Glycoprotein 53 is another protein, localized in lysosomal granules. It gets excreted via the platelet canalicular system onto the cell membrane upon stimulation. It is a 53- $\mathrm{kD}$ glycoprotein that has been identified by Nieuwenhuis et al. [13] and is also used as a marker of platelet activation.

Previous studies have demonstrated that damage of the coronary arterial wall induces platelet activation and may be associated with a higher predisposition to restenosis [14]. The application of artificial devices into coronary arteries implicates an additional thrombogenic potential. Clinical investigations showed an increased P-selectin degranulation in patients with subacute stent thrombosis [15]. The metallic mesh and shear forces contribute to further activation of platelets. Thereby, the probability of thrombotic occlusion may be amplified [5].

CD41a and CD42b did not show significant changes in MCFI. CD41a used in this study detects the allb-chain of glycoprotein IIb-IIIa. IIb-IIIa complexes are already highly expressed with 50,000 to 80,000 copies on unstimulated platelet surfaces. They are mainly involved in aggregation. Ib-V-IX complexes, as detected by $C D 42 b$, mediate platelet adhesion via von Willebrand factor. About 25,000 antigen complexes are located on cytoplasmatic membranes of resting platelets [16]. The observation time of $10 \mathrm{~min}$ is probably too short and the activating impact is not powerful enough to induce significant changes in these parameters [17]. In addition, minor changes of antigens CD41a and 42b may also be difficult to identify by relative expression with MCFI due to the high density of these antigens on the cytoplasmatic surface of platelets.

Clinical observations of multiple stent implantation [18] and multivessel stenting [19] demonstrated a higher incidence of in-stent restenosis. In our in vitro model stent length was associated with an increased expression of platelet antigens. An enhanced platelet activation may be one reason for this observed phenomenon in vivo. Time until stent thrombosis was dependent on stent length as well. Longer stents thrombosed earlier demonstrating that platelets are only one part involved in the process of stent closure and instent restenosis.

Changes in stent composition and design may be advantageous. Since randomized trials comparing different sizes and designs do not exist, this in vitro model in combination with flow cytometry may provide a sensitive diagnostic system for analyzing activation dependent alterations in platelets and may attribute to further improvement of stent design and biocompatibility.

\section{References}

1. Sigwart U, Puel J, Mirkovitch V; Joffre F; Kappenberger L. Intravascular stents to prevent occlusion and restenosis after transluminal angioplasty. N Engl J Med 1987:316:701-6.

2. Senruys PW, de Jaegere P, Kiemeney' F, Macaya C, Rutsch W, Heyndrickx G, Emanuelsson $H$, Marco J, Legrand V, Materne P, Belardi J, Sigwart U. Colombo A, Goy JJ, van den Heuvel P. Delcan J, Morel MA, for the Benestent Study Group. A comparison of balloon-expandable stent implantation with balloon angioplasty in patients with coronary artery disease. N Engl J Med 1994;331:48995.

3. Fischman DL, Leon M, Baim DS, Schatz RA, Savage MP, Penn I, Detre K, Veltri L. Ricci D, Nobuyoshi M, Cleman M, Heuser R. Almond D, Teirstein PS, Fish D, Colombo A, Brinker J, Moses J, Shaknovich A, Hirshfeld J, Bailey S. Ellis S, Rake R, Goldberg S, for the Stent Restenosis Study Investigators. A randomized comparison 
of coronary stent placement and balloon angioplasty in the treatment of coronary artery disease. N Engl J Med 1994,331:496-501.

4. Scrruys PW, Strauss BH. Beatt KJ, Bertrand ME, Pucl J, Rickards AF, Mcier B, Goy JJ, Vogt P, Kappenberger L, Sigwart U. Angiographic follow-up after placement of a self-expanding coconary artery stent. N Engl J Med 1991;324:13-7.

5. Mak KH. Belli G, Ellis SG, Moliterno DJ. Subacute stent thrombosis: cvolving issues and current concepts. J Am Coll Cardiol 1996;27:494-503.

6. Neumann FJ, Gawaz M, Ott I, May A, Mössmer G, Schömig A. Prospective evaluation of hemostatic predictors of subacute stent thrombosis after coronary Palmaz-Schatz stenting. J Am Cog Cardiol 1996;27:15-21.

7. Beythicn $C$. Terres W, Hamm CW. In vitro model to test the thrombogenicity of coronary stents. Thromb Res 1994;75:581-90.

8. Gutensohn K, Beythien C, Bau J, Meinertz T, Kühnl P. Flow cytometric analysis of coronary stent-induced alteration of platelets antigens in an in vitro model. Thromb Res 1997;86:49-56.

9. Gawaz M. Neumann FJ, Ott I, May A, Schöming A. Platelet activation and coronary stent implantation. Circulation 1996:94:279-85. 10. Ruf A, Patscheke U. Flow cytometric detection of activated platelets. Comparison of determining shape change, fibrinogen binding and P-selectin expression. Sem Thrombosis Hemostasis 1995;21:150

11. Shattil JS. Cunningham M, Hoxie JA. Detection of activated platelets in whole blood using activation-dependent monoclonal antibodies. Blood 1987;70:308-15.

12. McEver RP, Martin MN. A monoclonal antibody to a membrane glycoprotein binds only to activated platelets. J Biol Chem 1984;259:9799-804.
13. Nieuwenhuis $\mathrm{KH}$, Oosterhout JJG, Rozemuller E, van Iwaarden F, Sixma JJ. Studies with a monoclonal antibody against activated platelets: evidence that a secreted 53.000-molecular weight lysosome-like granule protein is exposed on the surface of activated platelets in the circulation. Blood 1987;70:838-45.

14. Tschoepe D, Schultheiß HP, Kolarov P, Schwippert B, Dannehl K, Nicuwenhuis HK, Kehrel B, Strauer B. Gries FA. Platelet membrane activation markers are predictive for increased risk of acute ischemic events after PTCA. Circulation 1993;88:37-42.

15. Gawaz M, Neumann FJ, Ott I, May A, Rudiger S, Schöming A. Role of activation-dependent platelet membrane glycoproteins in development of subacute occlusive coronary stent thrombosis. Coronary Artery Disease 1997;8:121-28.

16. Nurden AT. Human platelet membrane glycoproteins. In: Bloom AL, Forbes CD, Thomas DP, Tuddenham EGD, editors. Haemostasis and Thrombosis, $3^{\text {rd }}$ Edition, Vol. 1. Churchilll Livingstone, 1994:115-65.

17. Mellgren K, Friberg LG, Hedner T, Mellgren G, Wadenvik $H$. Blood platelet activation and membrane glycoprotein changes during extracorporeal life support (ECLS). In vitro studies. Int J Artif Organs 1995; 18:315-21.

18. Fernández-Avilés F, Alonso JJ, Durán JM, Gimeno F, San Román JA, Fuente L, Munoz JC, Bermejo J, Garcia E, Paniagua J. Clinical and angiographic restenosis after coronary stenting: Incidence and predictors. Eur Heart J 1996;17(Suppl):307 (abstr).

19. Moussa I, Di Mario C, Di Francesco L, Reimers B, Blengino S, Ferraro M Martini G, Tobis J, Colombo A: Multivessel stenting without anticoagulation: immediate and short-term outcome. Eur Heart J 1996;17(Suppl):218 (abstr). 